\title{
3. Coral Bell: A Preoccupation with Armageddon
}

\author{
Geoffrey Barker
}

In mid-2005 Coral Bell, aged eighty-two, sat with me in an Australian National University (ANU) conference room for more than two hours discussing her life and work as perhaps Australia's most eminent and respected international security scholar. A lengthy article based on our conversation was published on 29 July 2005 in The Australian Financial Review Magazine. ${ }^{1}$ Coral later told me, 'You have made me famous'. In fact I had barely done justice to her, but I did not appreciate the extent of my inadequacy until early 2013 when I read her own short memoir entitled, 'A Preoccupation with Armageddon' - a marvellously insightful, witty, and personal account of her life and career.

It was not just that her writing was superior to my hasty journalism. It was also that I missed some key aspects of her life - most notably the approach to her, by colleagues in the old Department of External Affairs in 1947, that she act as a spy for the Soviet Union. The approach, which she laughed away, was subsequently revealed in January 2012 by Professor Desmond Ball in an article published in The Australian newspaper. I confess that I was overawed by the grey-haired grandmotherly figure with the white shawl over her shoulders sipping coffee with me: I had known and admired her work for many years and I had enjoyed her company when I was a Visiting Fellow at the ANU Strategic and Defence Studies Centre. I just didn't ask the right question at the time.

Now, following Coral's death in September 2012, I have the opportunity to revise and update The Australian Financial Review Magazine article for this publication. I hope I can serve her better in death than I could in life because Coral Bell deserves to be recognised and memorialised as a great international scholar who was present at the creation of the post-War world of US-Soviet superpower competition and who, to her last days, remained an astute analyst of the emerging post-Cold War world of rising state powers like China and India and non-state players like Jihadist terrorists. Coral Bell was a woman who understood and appreciated the complexities and contradictions of international relations. She understood the importance of history and of patience in dealing with international disputes and crises. Her views were conservative and realist, but of the English realist school labelled 'rationalism' which sought to blend

1 This is a revised version of Geoffrey Barker, 'The Analyst', The Australian Financial Review Magazine, 29 July 2005. 
the pessimism of realism with the optimism of liberal internationalism. She remained fundamentally optimistic about the future of the world because, as she said, 'I have seen far more dangerous times'.

Unlike many of her colleagues Coral did not pursue public recognition. She did not play the media game and seek to promote her views. That scholarly modesty might explain why it was not until 2005 that Coral received her Order of Australia in the Queen's Birthday Honours. To her, international security issues were too profound to be reduced to the often glib formulas to which journalists seek to reduce complex issues. 'My work is a sort of meditation on history', she told me. 'History is what you have to be guided by. You can't change everything overnight and history teaches the necessity for patience'. She also recalled with approval the words of the great conservative philosopher Michael Oakeshott that international politics was about maintaining an even keel in 'a boundless and bottomless sea' where there were no safe harbours. ${ }^{2}$

Bell's optimism was reinforced by the fact that she had, as she said, 'grown up when the world was preparing for war'. 'I think on the whole there has been a very great improvement in the way people think. The world was far more dangerous during the outbreak of war in 1939 and at the beginning of the Cold War in 1946 that it is at present. That's because we survived the Second World War. In the years between 1946 and 1989 we survived the very great dangers of the bipolar nuclear world with the tension between the United States and the Soviet Union. In 1962 and 1983 the world was very close to the brink. I don't see any such closeness at the moment'.

'The Jihadists are an awful problem, of course, but they are not as devastating a problem as nuclear war between the great powers', Bell said. 'We calculated there would be 300 million dead in the first 60 minutes if there were all-out war between the US and Soviet Union. That's a reason for an optimistic view. We have survived all that and I think we can survive a lot more'.

To the end of her life Bell's realism attracted her to the notion that a Europeanstyle concert of powers could preserve peace more effectively than the so-called balance of powers that underpins standard realism. Her two late papers Living with Giants and The End of the Vasco da Gama Era both argued for a concert of powers to oversee the re-emerging multi-polar world of large and powerful states, especially in the Asia-Pacific region. ${ }^{3}$ It is a fascinating and controversial view that is still being debated in realist circles.

2 See Michael Oakeshott, 'Political Education', Inaugural Lecture delivered at the London School of Economics and Political Science, 6 March 1951.

3 See Coral Bell, Living with Giants: Finding Australia's Place in a More Complex World, Strategy Report, Australian Strategic Policy Institute, Canberra, April, 2005; and The End of the Vasco da Gama era: The Next Landscape of World Politics, Lowy Institute Paper 21, Lowy Institute for International Policy, Sydney, 2007. 
Coral Mary Bell was born in Sydney in 1923, the middle child and only daughter of a poor Anglo-Irish family. Her mother died when she was seven and her father, an electrical contractor who was out of work for almost eight years during the depression, sent her to live with relatives at Eden on the south coast of NSW where she attended St Joseph's convent school and later returned to attend Sydney Girls High School.

The nuns at Eden taught Bell what she called 'the most useful lesson I ever had'. The nuns taught what Bell remembered as 'a very Catholic version of history', but she knew that state examiners would expect a Protestant version. 'So at age eleven', she said, 'I still remember cheerfully describing a fourteenth century character called Wycliffe as 'the morning star of the reformation' for my Protestant examiners and as a 'dissolute and heretic monk' for my Catholic examiners. Complexity did not intimidate Coral Bell.

From a young age Bell started bumping into the historical crises that ensured her work was informed by much more than reports and texts. She recalled the 1938 Munich Crisis as 'the first event in the history of my times to affect me intellectually and emotionally'. 'My preoccupation with crisis as diplomatic process began there ... and I've been writing about it ever since', she said. Bell heard the explosions and gunfire when Japanese mini-submarines attacked Sydney in June 1942 and she had a vivid memory of hearing of the atomic bomb attack on Japan in August 1945, the year in which she graduated in Arts from Sydney University. As she said in her private memoir: 'I have never been, in any of its senses, a party girl ...'

During the war, while a university student, this serious young woman had a job doing secret work for the navy in the university's national physics laboratory degaussing (demagnetising) warships to protect them from mines. Just down the corridor from where she worked other scientists and engineers were working on radio location (radar) devices. She saw this experience as a key to her career. 'For three war years I spent my days surrounded by scientists and technicians. I think the reason I took to strategic studies was that I had started in the field of weaponry. Degaussing and radio location were things for the troops. I think I acquired a certain interest in strategic hardware at the time. Likewise, an empiricist mindset which is still with $\mathrm{me}^{\prime}$, she said.

Having read mainly English, history and philosophy, in 1944 Bell sat an examination for admission to the new diplomatic service being set up by the External Affairs Minister Dr Herbert Vere ('Doc') Evatt. She was the only woman in an intake of ten cadets which included Donald Horne (briefly) and the legendary public servants Bill Pritchett and Bob Furlonger. It was an age of innocence at the Department of External Affairs. Bell recalled that there 
was no security. 'We left our offices open when we went to lunch which we would eat on the lawns outside while foreign diplomats were allowed to wander unescorted around the building. Things were very primitive', she said.

Bell spent six years at External Affairs working mainly on policy surrounding the founding of the United Nations and ANZUS (Australia New Zealand United States) Treaty. In 1948 she was posted to New Zealand which she said felt like being awarded 'the wooden spoon' although the posting was 'reasonably interesting'. It was while Bell was working in the United Nations Division of External Affairs in Canberra that she received the espionage approach from colleagues she described in her memoir as 'rather charming spies' who she 'assumed to be friends'.

They were Fred Rose, an anthropologist and open Communist Party member, and External Affairs colleagues Jim Hill, brother of communist leader Ted Hill, and Ric Throssell, son of well-known communist Katharine Susannah Prichard. One day, after lunch, Throssell said to Bell, 'some of us think that the Soviet Union ought to see these documents'. Bell wrote, 'I assumed he was joking so I laughed merrily and said something to the effect that it sounded like splendid way to get oneself into jail'. Professor Desmond Ball, who reported this exchange after conversations with Bell, wrote that Bell believed Throssell told Burton of her 'frivolous' response and that Burton 'acted fast' to remove her from his central policy division. 'Bell firmly believes that Burton provided "top cover" for the spies in his department', Ball wrote. In her memoir Bell describes Burton as 'the most controversial and ambiguous' of the three intellectually dominant young officials in External Affairs (the others were Paul Hasluck and Arthur Tange). She also writes that she believes Burton, not Evatt, was 'doing the sheltering' of the Communist spies in the Department. But despite her apparent suspicions, she stops short of making the contentious and contested claim that Burton was himself a spy.

In 1951, Bell resigned from the External Affairs department feeling, she said, 'like a cog in a large machine' and sailed to the UK to study at the London School of Economics (LSE) and to embark on her extraordinary career as a university teacher and researcher. She did not marry. 'In my day you were told that if you married you were deemed to have resigned from the diplomatic service. So I gave up the idea', she said. Like so many of her contemporaries, war claimed her first sweetheart. In a brief moment of undisguised sadness Bell told me:, 'He was killed during a landing in Papua New Guinea. They told me he was shot in the head and died instantly without suffering. I hope that is true'.

At LSE she was an evening student doing research work during the day at the Royal Institute of International Affairs. Working with the historian Arnold J 
Toynbee she wrote the Institute's Survey of International Affairs for $1954 .{ }^{4}$ Bell admired Toynbee, describing him to me as 'splendid, delightful, loyal, modest, diffident'. It was at the LSE too that she came under the influence of the noted English international relations theorist Martin Wight whom she called 'the chief intellectual influence of my life'. She was present when the conservative Michael Oakeshott took over the LSE leadership following the retirement of the socialist Harold Laski. Among her colleagues was Karl Popper whose great book The Open Society and Its Enemies she greatly admired.

Appointed the first international relations lecturer at Manchester University in 1956 Bell started work on her PhD on the US Cold War strategy labelled Negotiation from Strength. ${ }^{5}$ A Rockefeller Fellowship took her to the US where she met the giants who created the modern bipolar world-George Kennan, the author of the US containment policy, Dean Acheson and Paul Nitze. And J Robert Oppenheimer, the father of the atomic bomb who, she said, gave her the first clue about US strategy in the nuclear world when he directed her to a top secret document written by Nitze. Bell said Oppenheimer 'looked like a being from outer space'. He had lost his security clearances due to past communist associations and was less discreet than some others, she said. Bell's work was later much admired by Henry Kissinger.

In 1961 Bell was appointed the first Senior Lecturer in International Relations at the University of Sydney. She returned to England to a Readership at the LSE in 1965 and in 1972 was appointed Professor of International Relations at the University of Sussex. In 1977 she returned to The Australian National University 'to spend my last ten years before retirement in my native land and in a research appointment'. From 1988 until her death she was a Visiting Fellow at the ANU Strategic and Defence Studies Centre where, to her last days, she continued to hone her craft as a compelling lecturer and a prolific and elegant writer. 'I suppose', she wrote in her memoir, 'I was one of the last generation to feel one could pursue a career on both sides of the world without any conflict of loyalties'. ${ }^{6}$

In his 2003 Boyer Lecture, Professor Owen Harries spoke about Coral's 'ability to cope with and enjoy complexity', he said: 'there is nothing simplistic or crude about her analysis'. To ANU Professor Emeritus Paul Dibb, Bell is simply, 'one of the great unrecognised and unsung strategic experts in this country. During the Cold War, she did absolutely magnificent work on the central balance between the US and Soviet Union and what she called the 'signalling' in their relations.'

4 Survey of International Affairs for 1954, Oxford University Press, London, 1956.

5 See Coral Bell, Negotiation from Strength: A Study in the Politics of Power, Chatto \& Windus, London, 1962, and Alfred A. Knopf, New York, 1963.

6 Coral Bell, 'A Preoccupation with Armageddon, unpublished memoir, Canberra, 2012. 
In a handsome tribute to Bell, Henry Kissinger wrote in his book, Does America Need a Foreign Policy: 'The Australian scholar Coral Bell has brilliantly described America's challenge: to recognise its own pre-eminence but to conduct its policy as if it were still living in a world of many centres of power' ${ }^{7}$ Australia and the world are poorer for the loss of her wisdom, judgement and insight.

7 Henry Kissinger, Does America Need a Foreign Policy: Toward a Diplomacy for the 21st Century, Simon \& Schuster, New York, 2001. 
This text taken from Power and International Relations:

Essays in honour of Coral Bell, edited by Desmond Ball and Sheryn Lee, published 2014 by ANU Press, The Australian National University, Canberra, Australia. 